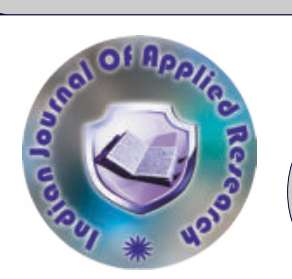

Psychiatry

\title{
STUDY OF VITAMIN D DEFICIENCY IN PATIENTS WITH DEPRESSION- WHETHER IT IS THE REASON FOR THE HIGH RATES OF SOMATIC PRESENTATION OF DEPRESSION.
}

\section{Debasish Sanyal*}

\section{Priya Mukherjee}

HOD, Dept. of Psychiatry, KPC Medical College \& Hospital, Kolkata, West Bengal, India. ${ }^{*}$ Corrsponding Author

PGT, Dept. of Psychiatry, KPC Medical College \& Hospital, Kolkata, West Bengal, India.

ABSTRACT

Background: Several studies have shown a relationship between depression and low levels of Vitamin D in the body. At the same time, somatisation is found to be a significant complaint in many patients of depression. Whether somatisation has any relationship with the low levels of Vitamin $\mathrm{D}$, needs further research.

Aims: To compare the prevalence of Vitamin D deficiency between depressed and non depressed subjects, and see if somatic presentation of depression has any correlate with Vitamin D deficiency.

Design: Observational, cross-sectional, hospital- based study.

Materials \& Methods: The study was conducted in the Department of Psychiatry, in a Private Hospital. Diagnosed MDD patients consenting to participate in the study, \& sex matched controls, comprising of close family members of patients were selected. Detailed assessment of depression symptomatology was done. Assessment of somatization was done using Bradford Somatic Inventory. Blood samples were collected for routine tests and Vitamin D (total) estimation.

Results: In the group of MDD patients, the mean age of females is 52 years, \& mean age of males is 50 years. In the MDD group, the mean Vitamin D level is 17.12; in the control group, the mean Vitamin D level is 22.19. The difference is statistically significant. Among MDD patients, $70 \%$ had deficiency of Vitamin D. In the Severe somatic symptom category, $68.3 \%$ had deficiency of Vitamin D; in the Mild somatic symptom category, $66.7 \%$ had deficiency of Vitamin D. The difference is not statistically significant.

Conclusion: Depression patients have significantly higher proportion of Vitamin D deficiency cases. Depressed patients with higher number of somatic symptoms have lower vitamin D level, but the difference is not significant.

\section{KEYWORDS : Vitamin D, depression, somatic presentation.}

\section{INTRODUCTION:}

Vitamin D is made in the skin from exposure to sunlight ${ }^{1,2,3,4}$. Vitamin D exists in two forms- Vitamin $\mathrm{D}_{2}$ \& Vitamin $\mathrm{D}_{3}$. Ultra Violet $\mathrm{B}$ light from the sun hits the skin, and humans synthesize vitamin $\mathrm{D}_{3}$. Humans cannot make $\mathrm{D}_{2}$. The Vitamin $\mathrm{D}$ that comes from the skin is biologically inert. It undergoes the first hydroxylation in the liver, by the enzyme Vitamin D-25-hydroxylase, to $25(\mathrm{OH}) \mathrm{D}^{1,5}$. 25(OH) D undergoes a further hydroxylation, in the kidneys, by the enzyme $25(\mathrm{OH}) \mathrm{D}-1$-hydroxylase to form the biologically active form of vitamin $\mathrm{D}^{1,5}$. The active form stimulates intestinal calcium absorption ${ }^{6}$. Vitamin D receptors are present in most of the tissues in the body ${ }^{7,8}$. Vitamin D has a wide range of actions in the body, like inhibition of cell proliferation and inducing terminal differentiation, inhibition of angiogenesis, stimulation of insulin production, inhibition of renin production, and stimulation of macrophage cathelicidin production, ${ }^{9,10}$.

Vitamin D Deficiency has been defined historically, and recently recommended by the Institute of Medicine (IOM) as a $25(\mathrm{OH}) \mathrm{D}$ level of less than $0.8 \mathrm{IU}$. Vitamin D insufficiency is defined as a $25(\mathrm{OH}) \mathrm{D}$ level of $21-29 \mathrm{ng} / \mathrm{mL}^{11,12,13,14,15,16,17}$. Vitamin D Deficiency is common in Australia, Middle Eastern countries, India, Africa, and South America $^{18,19}$.

It is postulated, that Indians have a high prevalence of Vitamin D Deficiency, because of ${ }^{18,19}$ :-

- Changing food fads and food habits like high fibre diet, containing phytates, phosphates.

- Genetic factors like having increased 25(OH)D-24- hydroxylase, which degrades $25(\mathrm{OH}) \mathrm{D}$ to inactive metabolites; Vitamin D Binding Protein.

- With modernization, the number of hours spent indoor has increased.

- Increased pollution can hamper the ultraviolet rays.

- Cultural and traditional habits prevalent in certain religions.

Complications of Vitamin D Deficiency include ${ }^{11}$ :-

- Rickets

- Osteomalacia

- Osteoporosis

- Tetany

- Other possible complications include:-

- Hypertension,

- Depression,

\section{- Cardiovascular disease,}

\section{- Increased risk of cancer}

Many studies have reported a beneficial effect of Vitamin D supplementation on musculoskeletal diseases, aches \& pains, or other complaints. The discovery of Vitamin D receptors in muscle cells prompted investigators to look for a muscle analogue of Osteomalacia. Because Vitamin D supplementation may enhance muscle strength, supplementation could also be an easy and inexpensive way to manage nonspecific musculoskeletal pain.

Psychiatric disorders, especially depression, are also speculated to be dependent on Vitamin D status ${ }^{20,21}$. The possibility of the role of Vitamin D is suggested by the presence of Vitamin D receptors in certain areas of the brain, like the cingulate cortex, the thalamus, the cerebellum, the substantia nigra, the amygdala, and the hippocampus ${ }^{22}$. Many of these areas have $1 \alpha$-hydroxylase enzymes, which are able to metabolize $25(\mathrm{OH}) \mathrm{D}$ to $1,25(\mathrm{OH}) 2 \mathrm{D} 3^{23}$. Vitamin D may play a key role in the pathophysiology of depression. Many studies have shown the existence of Vitamin D, its receptors (VDR) and associated enzymes (CYP 24A1, CYP 27B1) in many areas of the brain, indicating the role of Vitamin $\mathrm{D}$ as a neurosteroid hormone, involved in activities like neuroprotection, neuro-immunomodulation, brain development and other brain functions ${ }^{24}$. Literature says that upregulation of inflammatory cytokines in the brain, may be associated with depression ${ }^{25}$. Vitamin D is possibly one of the modulators in the association between depression and inflammatory response, by virtue of its effect on the immune system ${ }^{26,27}$.

Somatisation in Depression may be caused because of:-

- Lack of linguistic skills to express their emotional experience (Prince, 1987).

- Influence of culture in altering disease experience ${ }^{28}$.

- Stigma attached to mental illness (i.e. its emotional distress) causes the depressive experience to be reconstructed through somatization to make it less socially stigmatizing ${ }^{29}$.

In a clinical study, by Bagadia in 1970, of 233 cases of depression, somatic symptoms were the most common complaint $(34 \%)^{30}$. Similar findings were reported by Gada in $1982^{31}$, Raguram et al in $1996^{32}$, and in a Kolkata study by Choudhury et al in $2001^{33}$. 
Volume - 11 | Issue - 01 | January - 2021 | PRINT ISSN No. 2249 - 555X | DOI : 10.36106/ijar

- To compare the prevalence of Vitamin D deficiency between depressed and non depressed subjects.

- To see if somatic presentation of depression has any correlate with Vitamin D deficiency.

\section{SETTINGS AND DESIGN:}

- Subjects were from a large private hospital.

- An observational, cross-sectional study was done.

\section{INCLUSION CRITERIA:}

- Aged 18-65 y.

- Meeting DSM-5 criteria for depression.

\section{EXCLUSION CRITERIA:}

- Pregnancy.

- Signs of rickets.

- Use of Vitamin D in the last 4 months.

- Erythrocyte Sedimentation Rate $>30 \mathrm{~mm} / \mathrm{h}$.

- Use of statins, cyclosporins, or oral steroids.

- Chronic illness (like hepatic, renal, dermatological disorders).

- Taking antidepressants.

- Smokers

\section{DESIGN:}

- Diagnosed MDD patients consenting to participate in the study were selected.

- Sex matched Controls, comprising of close family members of patients were also selected.

- Detailed assessment of depression symptomatology was done; assessment of somatization was done using Bradford Somatic Inventory (BSI).

- Blood samples were collected for routine tests and Vitamin D (total) estimation. Deficiency was considered to be present when serum $25(\mathrm{OH})$ D levels are $<20 \mathrm{ng} / \mathrm{ml}$; insufficiency between 20 $30 \mathrm{ng} / \mathrm{ml}$ and sufficient when $>30 \mathrm{ng} / \mathrm{ml}$.

\section{BRADFORD SOMATIC INVENTORY (BSI):}

- The Bradford Somatic Inventory is a multi- ethnic inventory of FSCs (functional somatic complaints). It has 46 items which enquires about the FSCs during the previous month and, if the subject has experienced a particular symptom, based on the total score, FSCs are categorized into 3 grades. (A score $>40$ is considered to be the 'high' range, 26-40 'middle' range, and 0-25 'low' range).

\section{RESULTSAND DISCUSSION:}

The data was pooled and statistical analysis was done using SPSS version 26. Data was presented as percentages, means, and standard deviations. All tests were 2- tailed. A p- value of less than 0.05 was considered statistically significant ( $95 \%$ confidence interval). Discrete variables were compared using $\mathrm{x}^{2}$ test; categorical variables between groups were analysed using Pearson's Chi Square Test.

\section{Demographics}

Table 1- Shows the distribution of age across Depression \& Control groups, \& across Male \& Female sex.

\begin{tabular}{|c|c|c|c|c|}
\hline GROUP & SEX & MEAN AGE & SD & N \\
\hline \multirow{3}{*}{ CONTROL } & FEMALE & 51.00 & 13.348 & 39 \\
\cline { 2 - 5 } & MALE & 49.62 & 12.936 & 21 \\
\cline { 2 - 5 } & TOTAL & 50.52 & 13.112 & 60 \\
\hline \multirow{3}{*}{ DEPRESSION } & FEMALE & 52.08 & 11.370 & 39 \\
\cline { 2 - 5 } & MALE & 50.33 & 11.800 & 21 \\
\cline { 2 - 5 } & TOTAL & 51.47 & 11.453 & 60 \\
\hline \multirow{3}{*}{ TOTAL } & FEMALE & 51.54 & 12.330 & 78 \\
\cline { 2 - 5 } & MALE & 49.98 & 12.234 & 42 \\
\cline { 2 - 5 } & TOTAL & 50.99 & 12.268 & 120 \\
\hline
\end{tabular}

Table 1 shows that, in the group of MDD patients, the mean age of females is 52 years, \& mean age of males is 50 years. In the Control group, the mean age of females is 51 years, \& mean age of males is 50 years. So, it can be said that, females with depression are older than males with depression. However, the difference is not statistically significant.

\section{Vitamin D level in Control \& Depression groups}

Table 2- Shows the Vitamin D levels in Depression \& Control groups, \& across Male \& Female sex.

\begin{tabular}{|c|c|c|c|c|}
\hline GROUP & SEX & $\begin{array}{c}\text { MEAN } \\
\text { VITAMIN D }\end{array}$ & SD & N \\
\hline \multirow{3}{*}{ CONTROL } & FEMALE & 22.1085 & 16.04469 & 39 \\
\cline { 2 - 5 } & MALE & 22.3386 & 15.77115 & 21 \\
\cline { 2 - 5 } & TOTAL & $\mathbf{2 2 . 1 8 9 0}$ & 15.81552 & 60 \\
\hline DEPRESSION & FEMALE & 17.1164 & 6.15566 & 39 \\
\cline { 2 - 5 } & MALE & 17.1290 & 6.20956 & 21 \\
\cline { 2 - 5 } & TOTAL & $\mathbf{1 7 . 1 2 0 8}$ & 6.12175 & 60 \\
\hline \multirow{3}{*}{ TOTAL } & FEMALE & $\mathbf{1 9 . 6 1 2 4}$ & 12.33107 & 78 \\
\cline { 2 - 5 } & MALE & $\mathbf{1 9 . 7 3 3 8}$ & 12.12809 & 42 \\
\cline { 2 - 5 } & TOTAL & 19.6549 & 12.20944 & 120 \\
\hline
\end{tabular}

Table 2 shows that, in the MDD group, the mean Vitamin D level is 17.12 (17.116 in females \& 17.129 in males); in the control group, the mean Vitamin D level is 22.19 (22.109 in females \& 22.339 in males). The difference is statistically significant $(\mathrm{p}=0.031)$. So, it can be said that, patients with depression have significantly lower levels of Vitamin D, than their sex- matched controls. The Vitamin D level in depression patients fell in the 'Deficiency' category; while the serum Vitamin D level in the Control group fell in the 'Insufficiency' category. It was also observed that, females with depression have lower Vitamin $\mathrm{D}$ levels than males with depression. However, this difference was not statistically significant. In the control group also, it was observed that, females had lower Vitamin D levels than males. Here also, the difference was not statistically significant.

\section{Vitamin D level Categories in Control \& Depression groups}

Table 3- Shows the Vitamin D level Categories (Deficiency, Insufficiency \& Sufficiency) in Control \& Depression groups.

\begin{tabular}{|c|c|c|c|c|}
\hline & & CONTROL & DEPRESSION & TOTAL \\
\hline \multirow[t]{2}{*}{ DEFICIENCY } & $\begin{array}{l}\text { NO. OF } \\
\text { SUBJ. }\end{array}$ & 33 & 42 & 75 \\
\hline & $\%$ & $55.0 \%$ & $70.0 \%$ & $62.5 \%$ \\
\hline \multirow[t]{2}{*}{ INSUFFICIENCY } & \begin{tabular}{|c|} 
NO. OF \\
SUBJ.
\end{tabular} & 15 & 18 & 33 \\
\hline & $\%$ & $25.0 \%$ & $30.0 \%$ & $27.5 \%$ \\
\hline \multirow[t]{2}{*}{ SUFFICIENCY } & $\begin{array}{l}\text { NO. OF } \\
\text { SUBJ. }\end{array}$ & 12 & $\mathbf{0}$ & 12 \\
\hline & $\%$ & $20.0 \%$ & $0.0 \%$ & $10.0 \%$ \\
\hline \multirow[t]{2}{*}{ TOTAL } & $\begin{array}{c}\text { NO. OF } \\
\text { SUBJ }\end{array}$ & 60 & 60 & 120 \\
\hline & $\%$ & $100.0 \%$ & $100.0 \%$ & $100.0 \%$ \\
\hline
\end{tabular}

Table 3 shows that, in the MDD group, $70 \%$ of subjects had deficiency of Vitamin D, \& $30 \%$ had insufficiency of Vitamin D. In the Control group, 55\% had deficiency of Vitamin D, 25\% had insufficiency of Vitamin D, \& 20\% had sufficient Vitamin D. The difference is statistically significant $(p=0.001)$. Hence, it can again be said that, majority of the patients with depression had deficient Vitamin D. In this study, none of the patients with depression were found to have sufficient serum Vitamin D levels. Whereas, in the control group, 20\% of the subjects had sufficient Vitamin D levels.

\section{BSI Categories vs. Vitamin D Status}

Table 4- Shows the Vitamin D level Categories (Deficiency \& Insufficiency) in the BSI Categories of Mild, Moderate \& Severe.

\begin{tabular}{|c|c|c|c|c|}
\hline & & SEVERE & MODERATE & MILD \\
\hline \multirow{2}{*}{ DEFICIENCY } & NO. OF SUBJ. & 28 & 6 & 8 \\
\cline { 2 - 5 } & $\%$ & $68.3 \%$ & $85.7 \%$ & $66.7 \%$ \\
\hline \multirow{2}{*}{$\begin{array}{c}\text { INSUFFICIEN } \\
\text { CY }\end{array}$} & NO. OF SUBJ. & 13 & 1 & 4 \\
\cline { 2 - 5 } & $\%$ & $31.7 \%$ & $14.3 \%$ & $33.3 \%$ \\
\hline COUNT & $\begin{array}{c}60 \\
\text { (Depression pts.) }\end{array}$ & 41 & 7 & 12 \\
\hline & $100.0 \%$ & $100.0 \%$ & $100.0 \%$ & $\begin{array}{c}100.0 \\
\%\end{array}$ \\
\hline
\end{tabular}

Table 4 shows that, in the Severe BSI category, $68.3 \%$ of subjects had deficiency of Vitamin D, 31.7\% had insufficiency of Vitamin D. In the Moderate BSI category, $85.7 \%$ of subjects had deficiency of Vitamin D, $14.3 \%$ of subjects had insufficiency of Vitamin D. In the Mild BSI category, $66.7 \%$ of subjects had deficiency of Vitamin D, 33.3\% had insufficiency of Vitamin D. The difference is not statistically significant. In our study, we wanted to see whether the somatic complaints of depression had any correlation with low serum Vitamin 
$\mathrm{D}$ levels. It was observed in our study, that overall, depressed patients with somatic symptoms had low Vitamin D levels in serum, but the severity of the somatic symptoms (as per Bradford Somatic Inventory) did not correlate with the serum levels of Vitamin D, or categories of Vitamin D deficiency. No particular trend was found to be followed.

\section{To sum up, we can say that:}

- Depression patients have significantly higher proportion of Vitamin D deficiency cases.

- Lower Vitamin D level than control, group-difference significant.

- Females tend to have lower vitamin D level- difference non significant.

- Depressed patients with higher number of somatic symptoms have lower vitamin D level, difference non significant.

\section{Comparison with other studies:}

- A study by Zhao et al., on the adult US population found no association between serum concentrations of 25 -hydoxyvitamin $\mathrm{D}$ $(25(\mathrm{OH}) \mathrm{D})$ and depression, when adjusting for known confounders ${ }^{34}$.

- Bhatia et al. ${ }^{35}$ found low vitamin D level in various psychiatric illnesses including depression.

\section{LIMITATIONS OFTHE STUDY:}

- Small sample size.

- It was a hospital based study-so cannot be generalized to the entire population.

- Dietary patterns of the subjects, lifestyle, and timing of the study at different periods of the year- need further evaluation.

- Longitudinal follow up study was not done.

- Response to vitamin D replacement- not done.

\section{CONCLUSION:}

Although, there is adequate sunshine in India, high temperatures during the daytime and sultry and humid climate in many areas are the deterrents to follow the advice about sun exposure. Hence, food fortification with Vitamin D is a good option to solve this issue. Similarly food fortification and public health policies for Vitamin D supplementation and dietary guidelines might be needed.

\section{Financial Support and Sponsorship- Nil.}

Conflicts of Interest- There are no conflicts of interest.

\section{REFERENCES:}

1. Lips P, Hosking D, Lippuner K, Norquist JM, Wehren L, Maalouf G, et al. The prevalence of vitamin D inadequacy amongst women with osteoporosis: An prevalence of vitamin D inadequacy amongst women with osteoporat
international epidemiological investigation. J Intern Med. 2006; 260:245-54.

2. Nair R, Maseeh A. Vitamin D: The "sunshine" vitamin. J Pharmacol Pharmacother. 2012 Apr-Jun; 3(2): 118-126.

3. Silva MC, Furlanetto TW. Intestinal absorption of vitamin D: A systematic review. Nutr Rev 2018;76:60-76.

4. Norman AW, Henry HH. Vitamin D. In: Erdman JW, Macdonald IA, Zeisel SH, eds. Present Knowledge in Nutrition, 10th ed. Washington DC: Wiley-Blackwell, 2012

5. Jones G. Vitamin D. In: Ross AC, Caballero B, Cousins RJ, Tucker KL, Ziegler TR, eds. Modern Nutrition in Health and Disease, 11th ed. Philadelphia: Lippincott Williams \& Wilkins, 2014.

6. Moyad MA. Vitamin D: A rapid review: Side effects and toxicity. Dermatology Nursing. 2009;21(1)

7. Lappe JM, Travers-Gustafson D, Davies KM, Recker RR, Heaney RP. Vitamin D and calcium supplementation reduces cancer risk: Results of a randomized trial. Am J Clin Nutr. 2007; 85:1586-91

8. Chlebowski RT, Johnson KC, Kooperberg C, Pettinger M, Wactawski-Wende J, Rohan T, et al. J Natl Cancer Inst. 2008;100:1581-91.

9. Stolzenberg-Solomon RZ, Vieth R, Azad A, Pietinen P, Taylor PR, Virtamo J, et al. A prospective nested case-control study of vitamin D status and pancreatic cancer risk in male smokers. Cancer Res. 2006; 66:10213-9.

10. Stolzenberg-Solomon RZ, Hayes RB, Horst RL, Anderson KE, Hollis BW, Silverman DT. Serum vitamin D and risk of pancreatic cancer in the Prostate, Lung, Colorectal, and Ovarian Screening Trial. Cancer Res. 2009;69:1439-47.

11. Holick MF. Vitamin D deficiency. N Engl J Med. 2007; 357:266-81.

12. Heaney RP. Functional indices of vitamin D status and ramifications of vitamin D deficiency. Am J Clin Nutr. 2004; 80(6 Suppl):1706S-9S.

13. Malabanan A, Veronikis IE, Holick MF. Redefining vitamin D insufficiency. Lancet. 1998;351:805-6.

14. Heaney RP, Dowell MS, Hale CA, Bendich A. Calcium absorption varies within the reference range for serum 25-hydroxyvitamin D. JAm Coll Nutr. 2003; 22:142-6.

15. Hansen KE, Jones AN, Lindstrom MJ, Davis LA, Engelke JA, Shafer MM. Vitamin D insufficiency: Disease or no disease? J Bone Miner Res. 2008; 23:1052-60.

16. Bischoff-Ferrari HA, Can U, Staehelin HB, Platz A, Henschkowski J, Michel BA, et al. Severe vitamin D deficiency in Swiss hip fracture patients. Bone. 2008; 42:597-602.

17. Dietary reference intakes for calcium and vitamin D. Washington DC: The National Academies Press; 2011. IOM (Institute of Medicine).

18. Marwaha RK, Tandon N, Reddy DR, Aggarwal R, Singh R, Sawhney RC, et al. Vitamin $\mathrm{D}$ and bone mineral density status of healthy schoolchildren in northern India. Am J Clin Nutr. 2005; 82:477-82.

19. Thacher TD, Fischer PR, Strand MA, Pettifor JM. Nutritional rickets around the world: Causes and future directions. Ann Trop Paediatr. 2006;26:1-16.

20. Berk M et al. Vitamin D Deficiency may play a role in Depression. Med Hypotheses 2007; 69(6):1316-9. Epub 2007 May 11.
21. Bertone- Johnson ER. Vitamin D and the Occurrence of Depression: Causal Association or Circumstantial Evidence? Nutr Rev 2009 Aug; 67(8):481-92.

22. Prufer K, Veenstra TD, Jirikowski GF, et al. Distribution of 1,25-dihydroxyvitamin D3 receptor immunoreactivity in the rat brain and spinal cord. J. Chem. Neuroanatomy 16(2), 135-145(1999).

23. Eyles DW, Smith S, Kinobe R, et al. Distribution of the vitamin D receptor and 1 alphahydroxylase in human brain. J. Chem. Neuroanatomy 29(1), 21-30 (2005).

24. Kalueff AV, Tuohimaa P. Neurosteroid hormone vitamin D and its utility in clinical nutrition. Curr. Opin. Clin Nutrit. Metab.Care 10(1), 12-19 (2007).

25. Song C, Wang H. Cytokines mediated inflammation and decreased neurogenesis in animal models of depression. Prog. Neuropsychopharmacol. Biol. Psychiatry 35(3), 760-768(2011)

26. Mora JR, Iwata M, von Andrian UH. Vitamin effects on the immune system: vitamins A and D take centre stage. Nat. Rev. Immunol 8(9), 685-698 (2008)

27. Van Etten E, Stoffels K, Gysemans C, et al. Regulation of vitamin D homeostasis: implications for the immune system. Nutr. Rev 66(10 Suppl 2), S125-34 (2008).

28. R.Raguram. Stigma, Depression and Somatization in South India. American Journal of Psychiatry September 1996; 153(8):1043-9.

29. Laurence J Kirmayer. Cultural Considerations on Somatoform Disorders. American Laurence J Kirmayer. Cultural Con
Psychiatric Press 1984; pp 933-941.

30. V.N. Bagadia et al. Treatment of Mental Disorders in India. Progress in NeuroPsychopharmacology. Volume 3, Issues 1-3, 1979, Pages 109-118

31. Manilal Gada. Psychobiology of Depression. Indian Journal of Psychiatry, January 1987; 29(1): pp 15-31.

32. R.Raguram. Stigma, Depression and Somatization in South India. American Journal of Psychiatry September 1996; 153(8):1043-9.

33. Chowdhury et al. Stigma and Mental Illness: pilot study of laypersons and health care providers with the EMIC in rural West Bengal, India. International Medical Journal December 2000; 7(4):257-260

34. Zhao et al. No associations between serum concentrations of 25 hydroxy Vitamin D and Parathyroid hormone and Depression among US adults. British Journal of Nutrition; 104(11):1696-1700.

35. M.S. Bhatia et al. Vitamin D Deficiency among Psychiatric Outpatients. Delhi Psychiatry Journal 2014; 17(1): 113-116. 